\title{
Impact of Sowing Method and Humic Acid on Sesame (Sesamum indicum L.) Production
}

\author{
Kandil, Essam Esmail Esmail \\ Plant Production Department, Faculty of Agriculture - Saba Basha, Alexandria \\ University, Egypt
}

\begin{abstract}
To improve yield, its components and quality of sesame (Sesamum indicum L.), two different sowing methods and various humic acid levels were evaluated in at El-Horreya village, Abou El-Matamir, El-Behira governorate, Egypt, during two successive summer seasons of 2013 and 2014 in sandy loam soil. The two field experiments were design as split plot design with three replications. The treatments were distributed at random as follows; sowing methods (broadcasting or in ridges) were applied in the main plot, while humic acid levels (without, 1200, 2400 , and $3600 \mathrm{~g} / \mathrm{ha}$ ) at two doses with first and second irrigation were allocated in the subplot. The obtained results reported that broadcasting method and Humic acid at rate of $3600 \mathrm{~g} / \mathrm{ha}$., increased yield, its components and quality of sesame (Sesamum indicum L.) crop i.e. plant height $(\mathrm{cm})$, number of capsules/plant, capsule length $(\mathrm{cm})$, number of seeds/capsule, 1000seed weight (g), seed, straw and biological yields ( $\mathrm{kg} / \mathrm{ha}$ ), oil seed content $(\%)$, protein $\%, \mathrm{P} \%$, $\mathrm{K} \%, \mathrm{Fe}, \mathrm{Mn}$ and $\mathrm{Zn}$ concentration $\left(\mathrm{mg} \mathrm{kg}^{-1}\right)$ in seeds of sesame under study conditions.

KEYWORDS: Sesame, sowing method, humic acid, yield, components, oil, El-Behira, Egypt
\end{abstract}

\section{INTRODUCTION}

Sesame (Sesamum indicum L.) is considered as one of the important oil seed crops. Sesame has high oil content ( $46-64 \%)$ and a dietary energy of $6355 \mathrm{Kcal} / \mathrm{kg}$. The seeds serve as a rich source of protein $(20-28 \%)$, Sugar $(14-16 \%)$ and minerals (5-7\%), Thanvanathan et al. (2001). It is one of the most important crops grown for oil production in Egypt. The crop is grown for its seeds, which contain $50-60 \%$ oil, $8 \%$ protein, $5.8 \%$ water, $3.2 \%$ crude fiber, $18 \%$ carbohydrate, $5.7 \%$ ash and it is very rich in minerals such as $\mathrm{Ca}, \mathrm{P}$ and vitamin E (Dasharath et al., 2007). Also, sesame oil has a very high level of unsaturated fatty acids, which is assumed to have reducing effect on plasma cholesterol, as well as on coronary heart disease (Agboola, 1979). On contrary to the decline in production, the need for sesame is steadily growing for human consumption and health. Seed shattering, indeterminate growth habit , undeveloped cultivars, poor cultural practices and management, some diseases, low harvest index, and poor crop rotations (Uzun et al., 2004; Uzun and Cagirgan, 2009; Furat and Uzun, 2010) all contribute to lower production. Lack of mechanized harvest also increases the cost of production. Above all, the high cost of sowing sesame deters some farmers, causing to cease sesame production. Production practices should; therefore, be reconsidered for sustainable and profit table sesame farming.

Imoloame et al. (2007) reported that broadcasting method of sowing has produced taller sesame (Sesamum indicum L.) plants in the second season, greater number of flowers and pods per plant in both years and the average of two years data. Mkamilo and Bedigian (2007) attributed the yield increases of sesame are due both to development and use of improved varieties and improved agronomy practices and crop protection. The potential yield of 
sesame still is much higher than actual yield, as still much damage occurs by pests and diseases, insufficient weed control, to high levels of monocropping, lack of mechanization (amongst others causing seed shattering when not enough labour is available during harvest) and unrealized genetic potential. Potential yields are probably as high as $2000 \mathrm{~kg} / \mathrm{ha}$.

In addition, humic acid (HA) is one of the most important components of bioliquid complex. Because of its molecular structure, it provides numerous benefits to crop production. It helps break up clay compacted soils, assists in transferring micronutrients from the soil to the plant, enhances water retention, increases seed germination rates, improves water, air, and roots penetration, and stimulates development of microflora population in soils. Humic acid is not a fertilizer, but as considered as a compliment to fertilizer (Mackowiak et al., 2001). On this respect, Wahdan et al. (2006) and El-Bassiouny et al. (2014) indicated that humic acid (HA) is not a fertilizer as it does not directly provide nutrients to plants, but is a compliment to fertilizer. Its benefits include:

i) Addition of organic matter to organically-deficient soils; ii) increase root vitality, iii) improved nutrient uptake, iv) better formation and stability of soil aggregates, v) increased both water and fertilizer retention, and vi) stimulate beneficial microbial activity.

Humic acid increased significantly all morphological criteria (plant height, leaves number, fresh and dry weights of shoots), metabolism (photosynthetic pigment, total soluble sugar, total carbohydrates, total amino acids and proline), mineral contents ( $\mathrm{N}, \mathrm{P}, \mathrm{K}, \mathrm{Ca}$ and $\mathrm{Mg}$ ) and grain, straw and biological yields of both cultivars of wheat (El-Bassiouny et al., 2014). However, the following references enhance this facts. For instance, Singaravel et al. (1993) detected that the seed yield of sesame (Sesamum indicum L.) plants increased with increasing the addition rate of HA from 0 to $40 \mathrm{~kg} / \mathrm{ha}$., sprayed on the soil surface. However, yield of sesame was found to be greatest with nitrogen application along with humic acid over application of Azospirillum (Singaravel and Govindaswamy, 1998). Porass et al. (2010) stated that application of half of the recommended dose of $\mathrm{N}$ - fertilizer combined with Azospirillum and humic acid led to the highest significant increases in number of branches, number of capsules, 1000- seed weight, seed yield and oil percent, for Giza 32 cv. and Shandweel $1 \mathrm{cv}$. sesame (Sesamum indicum L.) genotypes.

The highest yields for peanut and sesame (Sesamum indicum L.) seeds achieved upon treating by gypsum application and humic acid as foliar spray increases $104.36 \%$ and $91.62 \%$ for peanut and sesame seeds, respectively over control plant. The highest values of proteins yield, $\mathrm{P}$ and $\mathrm{K}$ contents and oil yield were achieved upon treating by 4.76 tons/ha gypsum and foliar spray with $6 \mathrm{~g} \mathrm{H}$.A./l. Significant increases in proteins $\%, \mathrm{P} \%, \mathrm{~K} \%$, and oil \% and protein, $\mathrm{P}$ and $\mathrm{K}$ content and oil yield for sesame seeds were taken place due to gypsum application, foliar spray by humic and/or amino acids were obtained. The highest values were achieved for proteins yield, $\mathrm{P}$ and $\mathrm{K}$ contents and oils yield, with treating by 4.76 tons/ha., of gypsum and foliar spray with $6 \mathrm{~g} / \mathrm{l}$ humic acid (Eisa, 2011). 
The objective of this study was to investigate the effect of different two sowing methods and humic acid levels, on yield and yield components and quality of sesame (Sesamum indicum L.)

\section{MATERIALS AND METHODS}

Two field experiments were carried out to study effect of two sowing methods and four humic acid levels, on yield, yield components and quality of sesame (Sesamum indicum L.) cv. " Shandaweel 3". Field experiments were conducted in El-Horreya village, Abou El-Matamir, El-Behira governorate, Egypt, during the two successive summer seasons 2013 and 2014 in sandy loam soil. Some physical and chemical characteristics of the studied soil before planting are presented in Table (1) which, were determined according to Klute (1986) and Page et al. (1982).

Table (1): Physical and chemical properties of the experimental soil sites during 2013 and 2014.

\begin{tabular}{|c|c|c|}
\hline \multicolumn{3}{|c|}{ Soil characteristics } \\
\hline Properties & \multicolumn{2}{|c|}{ Seasons } \\
\hline Particle size distribution & 2013 & 2014 \\
\hline Sand $\%$ & 60.90 & 61.03 \\
\hline Silt \% & 10.60 & 10.05 \\
\hline Clay \% & 28.50 & 28.92 \\
\hline Soil texture $(\%)$ & Sandy loam & Sandy loam \\
\hline $\mathrm{pH}(1: 2.5$ water suspension) & 8.10 & 7.99 \\
\hline $\mathrm{EC}\left(\mathrm{dSm}^{-1}\right)$ & 2.10 & 1.95 \\
\hline \multicolumn{3}{|c|}{ Soluble Cations (meq/L.) } \\
\hline $\mathrm{Ca}^{++}$ & 7.60 & 9.10 \\
\hline $\mathrm{Mg}^{++}$ & 5.20 & 4.85 \\
\hline $\mathrm{Na}^{+}$ & 4.10 & 4.00 \\
\hline $\mathrm{K}^{+}$ & 0.20 & 0.25 \\
\hline \multicolumn{3}{|c|}{ Soluble Anions (meq/L.) } \\
\hline $\mathrm{HCO}_{3}^{-}$ & 2.00 & 1.95 \\
\hline $\mathrm{Cl}^{-}$ & 3.85 & 3.77 \\
\hline $\mathrm{SO}^{--}$ & 10.50 & 12.20 \\
\hline O.M. (\%) & 1.85 & 1.90 \\
\hline $\mathrm{CaCO}_{3}(\%)$ & 22.50 & 23.70 \\
\hline Available Mineral N(mg/kg) & 92.40 & 85.60 \\
\hline Available P $(\mathrm{mg} / \mathrm{kg})$ & 23.12 & 25.50 \\
\hline
\end{tabular}

The experiments were designed as split plot design with three replications, where the sowing methods (broadcasting or hills on ridges) at the rate of $10 \mathrm{~kg}$ seeds/ha were distributed at random within main plot, while humic acid levels (untreated, 1200, 2400, and $3600 \mathrm{~g} / \mathrm{ha}$ ) applied at sowing and first irrigation at two equal doses were allocated at random within the subplot. The humic acid (Techno potas- humic acid) analysis is presented in Table (2). 
Table (2). Techno potas- humic acid analysis

\begin{tabular}{l|c}
\hline \multicolumn{2}{c}{ Product analysis } \\
\hline Product name & Techno Potas- Humic acid \\
\hline Formula (W/W) & $12 \% \mathrm{~K}_{2} \mathrm{O}-\mathrm{HA} 75 \%$ \\
Potassium $\mathrm{K}_{2} \mathrm{O}$ (on dry basis) & $12 \%(\mathrm{~W} / \mathrm{W})$ \\
Humic acid (on dry basis) & $75 \%(\mathrm{~W} / \mathrm{W})$ \\
Moisture & $15 \%($ Max.) \\
$\mathrm{pH}$ & $9-10$ (Max.) \\
Water solubility & $95 \%$ (Min.) \\
\hline
\end{tabular}

The sub plot area was $10.5 \mathrm{~m}^{2}$ ( $3 \mathrm{~m}$ width and $3.5 \mathrm{~m}$ length) in broadcasting sowing method, while in ridges planting method, the sub plots consisted of 6 ridges 3.5 meters in length, $60 \mathrm{~cm}$ in width and $20 \mathrm{~cm}$ between hills. However, Nitrogen fertilizer was applied as urea fertilizer $(46 \% \mathrm{~N})$ at the rate of $75 \mathrm{~kg} \mathrm{~N} / \mathrm{ha}$, at two doses. Phosphorus fertilizer was applied before planting as Calcium- Super Phosphate $\left(15.5 \% \mathrm{P}_{2} \mathrm{O}_{5}\right)$ at the rate of $480 \mathrm{~kg} / \mathrm{ha}$. Potassium Sulphate $\left(48 \% \mathrm{~K}_{2} \mathrm{O}\right)$ was added before the second irrigation at rate of $120 \mathrm{~kg} / \mathrm{ha}$. Sesame (Sesamum indicum L.) cv. "Shandaweel 3" was sown on $10^{\text {th }}$ and $15^{\text {th }}$ of June in 2013 and 2014 seasons, respectively. The preceding crop was clover (Trifolium alexanderinum, L.) during both seasons of the study. All other agricultural treatments for growing sesame plants were done as recommended by the Ministry of Agriculture.

At harvest time 120 days from sowing stage, the following data were recorded: plant height $(\mathrm{cm})$, number of capsules/plant, capsule length $(\mathrm{cm})$, number of seeds/capsule, 1000- seed weight (g), seed yield, straw yield, biological yield $(\mathrm{kg} / \mathrm{ha}$ ), harvest index and oil seed content \% (was determined according to AOAC 1990).

Samples of sesame seeds were ground and $0.5 \mathrm{~g}$ powder of each was digested by concentrated mixture of $\mathrm{H}_{2} \mathrm{SO}_{4} / / \mathrm{HClO}_{4}$ acids according to Sommers and Nelson (1972). Nitrogen was determined by micro- Keldahl, according to Jackson (1976) and multiply by 6.25 to determine protein percentage. Phosphorus was determined, spectrophotometrcally, using ammonium molybdate/ stannus chloride method according to Chapman and Pratt (1978). Potassium was determined by a flame photometer, according to Page et al. (1982). Fe, Mn, and $\mathrm{Zn}$ concentrations were determined by using Atomic Absorption apparatus.

Data were, statistically, analyzed as a split plot design according to Snedecor and Cochran (1990). The least significant differences (LSD at 0.05) used to compare the treatment means using CoStat (2005) program.

\section{RESULTS AND DISCUSSION}

\section{A. Effect of sowing methods}

Results in Tables ( 3 and 4 ) showed that sowing methods and humic acid rates were, significantly affected most of the studied characters; i.e., plant height $(\mathrm{cm})$, number of capsules/plant, capsule length $(\mathrm{cm})$, number of 
seeds/capsule, 1000- seed weight (g), seed, straw and biological yields $\mathrm{kg} / \mathrm{ha}$., harvest index and oil seed content \% of sesame (Sesamum indicum L.). Whereas, the sowing sesame plants by broadcasting method recorded the highest mean values of most of the previous parameters i.e. yield, its components and oil content in sesame seeds, while the lowest ones were obtained by planting sesame plants in ridges as planting method. However, planting in ridges achieved the heaviest straw yield $\mathrm{kg} / \mathrm{ha}$. Meanwhile, there was no significant difference between both sowing methods on harvest index $(\mathrm{H} . \mathrm{I} . \%)$ during the second season. The similar results, more or less, were with agreement with those obtained by Imoloame et al. (2007).

Data of Table (5) revealed that there was no significant difference between planting methods respective $\mathrm{Zn}$ concentration in seeds of sesame in both seasons. Also, data in Table (5) showed that planting methods affected, significantly, on Fe and Mn contents in seeds during both seasons, while, planting methods affected, significantly, protein $\%$ and $\mathrm{K} \%$ in sesame seeds during first season of this study and $P$ content in the second season only. In addition, broadcasting method achieved the higher concentration of all the pervious studied characters. These could be due to intra-plant competition in the drilled crop compared with the broadcast crop (Imoloam, 2004).

\section{B. Effect of humic acid}

Humic acid levels had significant effects on most of the studied characteristics, where the highest level of humic acid (3600 g/ha.) gave the highest average values from these traits of sesame (Sesamum indicum L.) as compared with others rates of humic acid. However, the lowest mean values were obtained with untreated (without humic acid) during both growing seasons. Similar conclusion was also, suggested by Singaravel et al. (1993); Porass et al. (2010); Eisa (2011).

Hermann et al. (2000) reported that the positive effect of HA and organic fertilization on the yield capacity of soil consists of many components. The first, these components concerning nutrient supply to plants. The second, physical soil properties are affected resulting in differences in root penetration, gas exchange and water supply. Humic acid essentially helps the movement of micronutrients from soil to plant.

Data in Table (4) showed that oil content in sesame seeds increased with increasing H.A. up to $3600 \mathrm{~g} / \mathrm{ha}$. The increase of humic acid from 1200 up to $3600 \mathrm{~g} / \mathrm{ha}$., had increased, significantly, oil content of seeds. These findings were in agreement with those obtained by Thanvanathan et al. (2001).

Data of protein, $\mathrm{P}$ and $\mathrm{K} \%$ in sesame seeds presented in Table (5) showed that adding humic acid up to $3600 \mathrm{~g} / \mathrm{ha}$., exerted significant increase in $\mathrm{P}$ and $\mathrm{K} \%$. The highest mean value of $\mathrm{P}$ and $\mathrm{K} \%$ in seeds increased by using $3600 \mathrm{HA} / \mathrm{ha}$, in comparison with others treatments during both seasons. These results are in agreement with those of Antoun et al. (2010). 
However, Fe, Mn and $\mathrm{Zn}$ concentrations affected significantly by using humic acid rates, whereas, the highest values were recorded using $3600 \mathrm{~g} / \mathrm{ha}$. The micronutrient concentrations in seeds were within sufficient limits according to Benton et al. (1992).

The highest values of protein, $\mathrm{P}$ and $\mathrm{K}$ contents in seeds of sesame were achieved by soil application of humic acid. The application of all treatments recorded marked increases in the concentration of $\mathrm{Mn}$ and $\mathrm{Zn}$ in sesame seeds, in both seasons. From the obtained results it could be concluded that biofertilizer and organic materials like, compost, humic acid and compost tea could producing higher sesame yield quantity and quality. Moreover, application of such materials conserves the environment from chemical pollution hazards (Khaled et al. 2012). The above- mentioned data cope with the significance role of humic acid; whereas, it improves physical, chemical and biological properties of the soil and influences plant growth. In this concern, humic acids are important soil components; they can improve nutrient availability and have impact on other important chemical, biological, and physical properties of soils. Also, foliar application of humic acids increased the uptake of $\mathrm{P}, \mathrm{K}, \mathrm{Mg}, \mathrm{Na}, \mathrm{Cu}$ and $\mathrm{Zn}$ (Hussein and Hassan, 2011).

\section{Effect of Interaction effects}

Data in Tables (3, 4 and 5) illustrate the effect of interaction between sowing methods and humic acid levels on all of the studied characters i.e. yield, its components, protein, micronutrients and macronutrients in seeds of sesame (Sesamum indicum L.) during the two cropping seasons. Whereas, the highest mean values of the studied parameters were obtained by sowing sesame plants by broadcasting with humic acid at rate of $3600 \mathrm{~g} / \mathrm{ha}$., while the lowest ones were recorded with planting on ridges with untreated ( 0 humic acid) in both seasons. These results showed that sowing methods and humic acid rates act dependently on those pervious studied characters.

Increases in macronutrient concentrations in sesame seeds may be taken place due to the availability of them in the soil as a result of decreasing soil $\mathrm{pH}$ and salinity caused by the action of organic materials or biofertilizer. These results agreed with those obtained by Moussa et al. (2006) and Nasef et al. (2009). Furthermore, the relative increases of Fe, Mn and $\mathrm{Zn}$ concentrations in sesame seeds are depending on their available contents and their solubility in soil caused by soil amendments (Khaled et al. 2012). However, the micronutrient concentrations in seeds were within sufficient limits according to Benton et al. (1992).

\section{CONCLUSION:}

As a result of this two cropping seasons field study, it was concluded that yield, its components and quality of sesame crop increased with broadcasting method and humic acid at rate of $3600 \mathrm{~g} / \mathrm{ha}$., under study conditions at Abou El-Matamir, El-Behira governorate, Egypt. 
J. Adv. Agric. Res. (Fac. Agric. Saba Basha)

Table (3). Average of plant attributes of sesame (Sesamum indicum L.) as affected by sowing methods (M), humic acid rates (H.A.) and their interaction during 2013 and 2014 seasons

\begin{tabular}{|c|c|c|c|c|c|c|c|c|c|c|c|c|c|}
\hline \multirow[b]{4}{*}{ Attributes } & \multicolumn{13}{|c|}{ Season } \\
\hline & \multirow{3}{*}{$\begin{array}{c}\text { Humic } \\
\text { acid rates } \\
\text { (H.A.) } \\
\text { g/ha. }\end{array}$} & \multicolumn{6}{|c|}{2013} & \multicolumn{6}{|c|}{2014} \\
\hline & & \multicolumn{2}{|c|}{ Sowing methods (M) } & & & & & \multicolumn{2}{|c|}{ Sowing methods (M) } & \multirow[b]{2}{*}{$\begin{array}{c}\text { Average } \\
\text { (H.A.) }\end{array}$} & \multirow[b]{2}{*}{\begin{tabular}{|c} 
L.S.D. \\
(M) at \\
0.05
\end{tabular}} & \multirow[b]{2}{*}{$\begin{array}{c}\text { L.S.D. } \\
\text { (HA) } \\
\text { at } 0.05\end{array}$} & \multirow[b]{2}{*}{$\begin{array}{c}\text { L.S.D. (M } \\
\text { x HA) at } \\
0.05\end{array}$} \\
\hline & & Ridges & Broadcasting & $\begin{array}{c}\text { Average } \\
\text { (H.A.) }\end{array}$ & $\begin{array}{c}\text { L.S.D. } \\
\text { (M) at } \\
0.05\end{array}$ & $\begin{array}{c}\text { L.S.D. } \\
\text { (HA) } \\
\text { at } 0.05\end{array}$ & $\begin{array}{c}\text { L.S.D. } \\
\text { (M x } \\
\text { HA) at } \\
0.05 \\
\end{array}$ & Ridges & Broadcasting & & & & \\
\hline \multirow{4}{*}{$\begin{array}{c}\text { Plant height } \\
(\mathrm{cm})\end{array}$} & Untreated & 116.33 & 141.67 & \multirow{5}{*}{$\begin{array}{l}129.00 \\
126.83 \\
136.50 \\
147.17\end{array}$} & \multirow{5}{*}{9.34} & \multirow{5}{*}{7.84} & \multirow{5}{*}{17.44} & 125.67 & 151.33 & 138.50 & \multirow{5}{*}{8.40} & \multirow{5}{*}{17.12} & \multirow{5}{*}{38.10} \\
\hline & 1200 & 120.33 & 133.33 & & & & & 137.33 & 156.67 & 147.00 & & & \\
\hline & 2400 & 127.00 & 146.00 & & & & & 143.33 & 185.67 & 164.50 & & & \\
\hline & 3600 & 141.67 & 152.67 & & & & & 161.00 & 195.67 & 178.33 & & & \\
\hline \multicolumn{2}{|c|}{ Average (M) } & 126.33 & 143.42 & & & & & $141.83 b$ & $172.33 \mathrm{a}$ & \multirow{6}{*}{$\begin{array}{c}72.67 \\
87.33 \\
97.50 \\
112.17\end{array}$} & & & \\
\hline \multirow{4}{*}{$\begin{array}{c}\text { Number of } \\
\text { capsules/plant }\end{array}$} & Untreated & 67.83 & 82.33 & \multirow{5}{*}{$\begin{array}{c}75.08 \\
85.92 \\
92.25 \\
109.67\end{array}$} & & & & 61.67 & 83.67 & & & & \\
\hline & 1200 & 78.50 & 93.33 & & & & & 75.67 & 99.00 & & & & \\
\hline & 2400 & 76.83 & 107.67 & & 7.56 & 4.47 & 9.95 & 90.67 & 104.33 & & 4.93 & 6.55 & 14.59 \\
\hline & 3600 & 105.00 & 114.33 & & & & & 107.67 & 116.67 & & & & \\
\hline \multicolumn{2}{|c|}{ Average (M) } & 82.04 & 99.42 & & & & & 83.92 & 100.92 & & & & \\
\hline & Untreated & 1.93 & 2.87 & \multirow{4}{*}{$\begin{array}{l}2.40 \\
2.67 \\
2.77 \\
3.10\end{array}$} & \multirow{4}{*}{0.072} & \multirow{4}{*}{0.227} & & 1.96 & 2.87 & \multirow{4}{*}{$\begin{array}{l}2.42 \\
2.75 \\
2.57 \\
2.95\end{array}$} & & & \\
\hline Capsule & 1200 & 2.23 & 3.10 & & & & & 2.40 & 3.10 & & & & \\
\hline & 3600 & 2.83 & 3.37 & & & & & 2.70 & 3.20 & & & & \\
\hline Average & (M) & 2.34 & 3.13 & & & & & 2.36 & 2.98 & & & & \\
\hline Numbor of & Untreated & 30.67 & 37.67 & 34.17 & & & & 31.83 & 36.33 & 34.08 & & & \\
\hline $\begin{array}{l}\text { Number of } \\
\text { seeds/cansule }\end{array}$ & 1200 & 34.00 & 44.00 & 39.00 & & & & 35.93 & 40.00 & 37.97 & & & \\
\hline & 2400 & 37.33 & 46.67 & 42.00 & 1.90 & 2.03 & 4.52 & 36.67 & 44.67 & 40.67 & 1.97 & 1.77 & 3.95 \\
\hline & 3600 & 42.67 & 48.67 & 45.67 & & & & 40.50 & 51.17 & 45.83 & & & \\
\hline Average & (M) & 36.17 & 44.25 & & & & & 36.23 & 43.04 & & & & \\
\hline & Untreated & 3.17 & 3.60 & 3.39 & & & & 2.97 & 3.40 & 3.18 & & & \\
\hline 1000 seed & 1200 & 3.40 & 3.87 & 3.64 & & & & 3.20 & 3.77 & 3.48 & & & \\
\hline weight (g) & 2400 & 3.70 & 4.30 & 4.00 & 0.374 & 0.199 & 0.444 & 3.57 & 3.97 & 3.77 & 0.199 & 0.164 & 0.364 \\
\hline & 3600 & 4.07 & 4.60 & 4.34 & & & & 4.07 & 4.33 & 4.20 & & & \\
\hline Average & (M) & 3.59 & 4.09 & & & & & 3.87 & 3.45 & & & & \\
\hline
\end{tabular}


J. Adv. Agric. Res. (Fac. Agric. Saba Basha)

Table (4). Average of seed yield attributes of sesame (Sesamum indicum L.) as affected by sowing methods (M), humic acid rates (H.A.) and their interaction during 2013 and 2014 seasons.

\begin{tabular}{|c|c|c|c|c|c|c|c|c|c|c|c|c|c|}
\hline \multirow{4}{*}{ Attributes } & \multicolumn{13}{|c|}{ Season } \\
\hline & \multirow{3}{*}{$\begin{array}{c}\text { Humic } \\
\text { acid rates } \\
\text { (H.A.) } \\
\text { g/ha. }\end{array}$} & \multicolumn{6}{|c|}{2013} & \multicolumn{6}{|c|}{2014} \\
\hline & & \multicolumn{2}{|c|}{ Sowing methods (M) } & \multirow[b]{2}{*}{$\begin{array}{c}\text { Average } \\
(\mathbf{H})\end{array}$} & \multirow[b]{2}{*}{$\begin{array}{l}\text { L.S.D. } \\
\text { (M) at } \\
0.05\end{array}$} & \multirow[b]{2}{*}{$\begin{array}{c}\text { L.S.D. } \\
\text { (HA) } \\
\text { at } 0.05 \\
\end{array}$} & \multirow[b]{2}{*}{$\begin{array}{c}\text { L.S.D. } \\
\text { (M x H) } \\
\text { at } 0.05\end{array}$} & \multicolumn{2}{|c|}{ Sowing methods (M) } & \multirow[b]{2}{*}{$\begin{array}{c}\text { Average } \\
\text { (H.A.) }\end{array}$} & \multirow[b]{2}{*}{\begin{tabular}{|c|} 
L.S.D. \\
(M) at \\
0.05 \\
\end{tabular}} & \multirow[b]{2}{*}{$\begin{array}{c}\text { L.S.D. } \\
\text { (HA) } \\
\text { at } 0.05 \\
\end{array}$} & \multirow[b]{2}{*}{$\begin{array}{c}\text { L.S.D. } \\
\text { (M x HA) } \\
\text { at } 0.05\end{array}$} \\
\hline & & Ridges & Broadcasting & & & & & Ridges & Broadcasting & & & & \\
\hline \multirow{4}{*}{$\begin{array}{l}\text { Seed yield } \\
\text { kg/ha. }\end{array}$} & Untreated & 680.00 & 1246.00 & \multirow{5}{*}{$\begin{array}{c}963.00 \\
1195.83 \\
1240.83 \\
1443.33\end{array}$} & \multirow{5}{*}{273.00} & \multirow{5}{*}{432.94} & \multirow{5}{*}{963.42} & 606.67 & 763.33 & 685.00 & \multirow{5}{*}{197.05} & \multirow{5}{*}{244.64} & \multirow{5}{*}{544.41} \\
\hline & 1200 & 861.67 & 1530.00 & & & & & 760.00 & 846.67 & 803.33 & & & \\
\hline & 2400 & 948.33 & 1533.33 & & & & & 691.67 & 1343.33 & 1017.50 & & & \\
\hline & 3600 & 1200.00 & 1686.67 & & & & & 1213.33 & 1493.00 & 1353.33 & & & \\
\hline \multicolumn{2}{|c|}{ Average (M) } & 922.50 & 1499.00 & & & & & $817.92 b$ & 1111.67 & & & & \\
\hline \multirow{4}{*}{$\begin{array}{c}\text { Straw yield } \\
\mathrm{kg} / \mathrm{ha} .\end{array}$} & Untreated & 2970.00 & 4354.00 & \multirow{5}{*}{$\begin{array}{l}3662.00 \\
4000.83 \\
4292.50 \\
5161.67\end{array}$} & \multirow{5}{*}{273.00} & \multirow{5}{*}{432.94} & & 3043.33 & 4836.67 & 3940.00 & & & \\
\hline & 1200 & 3631.00 & 4370.00 & & & & & 3733.33 & 5053.33 & 4393.33 & & & \\
\hline & 2400 & 3351.67 & 5233.33 & & & & 963.42 & 3608.33 & 5423.33 & 4515.83 & 112.32 & 556.06 & 1237.41 \\
\hline & 3600 & 3993.33 & 6330.00 & & & & & 3980.00 & 6523.33 & 5251.67 & & & \\
\hline Avera & $(\mathbf{M})$ & 3486.00 & 5071.83 & & & & & 3591.25 & 5459.17 & & & & \\
\hline & Untreated & 3650.00 & 5600.00 & 4625.00 & & & & 3650.00 & 5600.00 & 4625.00 & & & \\
\hline Biological & 1200 & 4493.33 & 5900.00 & 5196.67 & & & & 4493.33 & 5900.00 & 5196.67 & & & \\
\hline yield $\mathrm{kg} / \mathrm{ha}$. & 2400 & 4300.00 & 6766.67 & 5533.33 & 309.36 & 452.70 & 1007.41 & 4300.00 & 6766.67 & 5533.33 & 309.36 & 452.70 & 1007.4 \\
\hline & 3600 & 5193.33 & 8016.67 & 6605.00 & & & & 5193.33 & 8016.67 & 6605.00 & & & \\
\hline Avera & $(\mathbf{M})$ & 4409.17 & 6570.83 & & & & & 4409.17 & 6570.83 & & & & \\
\hline & Untreated & 18.64 & 22.28 & 20.46 & & & & 16.63 & 13.63 & 15.13 & & & \\
\hline $\begin{array}{l}\text { Harvest } \\
\text { index \% }\end{array}$ & 1200 & 19.20 & 26.01 & 22.61 & & & & 16.98 & 14.48 & 15.73 & & & \\
\hline (H.I.) & 2400 & 22.05 & 22.74 & 22.39 & 1.41 & 1.87 & 4.16 & 16.17 & 20.03 & 18.10 & N.S. & 5.76 & 12.83 \\
\hline & 3600 & 23.10 & 21.06 & 22.08 & & & & 23.37 & 18.65 & 21.01 & & & \\
\hline Avera & $(\mathbf{M})$ & 20.75 & 23.02 & & & & & 18.29 & 16.70 & & & & \\
\hline & Untreated & 33.17 & 45.23 & 39.20 & & & & 34.53 & 38.67 & 36.60 & & & \\
\hline Oil seed & 1200 & 37.67 & 44.33 & 41.00 & & & & 47.60 & 51.27 & 49.44 & & & \\
\hline content \% & 2400 & 47.27 & 44.00 & 45.64 & 2.81 & 3.99 & 5.65 & 51.00 & 54.37 & 52.69 & 2.56 & 1.48 & 2.09 \\
\hline & 3600 & 42.23 & 53.97 & 48.10 & & & & 54.97 & 56.33 & 55.65 & & & \\
\hline Avera & $(\mathbf{M})$ & 40.09 & 46.88 & & & & & 47.03 & 50.16 & & & & \\
\hline
\end{tabular}

N.S.: Not significant at 0.05 level of probability. 
J. Adv. Agric. Res. (Fac. Agric. Saba Basha)

Table (5). Averages of protein \%, P \%, K\%, Fe, Mn and Zn concentrations ( $\mathrm{mg} / \mathrm{kg}$ ) of sesame (Sesamum indicum L.)as affected by sowing methods (M), humic acid rates (H.A.) and their interaction during 2013 and 2014 seasons

\begin{tabular}{|c|c|c|c|c|c|c|c|c|c|c|c|c|c|}
\hline \multirow{4}{*}{ Attributes } & \multicolumn{13}{|c|}{ Season } \\
\hline & \multirow{3}{*}{$\begin{array}{c}\text { Humic acid } \\
\text { rates (H.A.) } \\
\text { g/ha. }\end{array}$} & \multicolumn{6}{|c|}{2013} & \multicolumn{6}{|c|}{2014} \\
\hline & & \multicolumn{2}{|c|}{ Sowing methods (M) } & \multirow[b]{2}{*}{$\begin{array}{c}\text { Average } \\
\text { (HA) }\end{array}$} & \multirow[b]{2}{*}{$\begin{array}{c}\text { L.S.D. } \\
\text { (M) at } \\
0.05\end{array}$} & \multirow[b]{2}{*}{$\begin{array}{c}\text { L.S.D. } \\
\text { (HA) } \\
\text { at } 0.05 \\
\end{array}$} & \multirow[b]{2}{*}{$\begin{array}{c}\text { L.S.D. } \\
\text { (M x HA) } \\
\text { at } 0.05\end{array}$} & \multicolumn{2}{|c|}{ Sowing methods (M) } & \multirow[b]{2}{*}{$\begin{array}{c}\text { Average } \\
\text { (H.A.) }\end{array}$} & \multirow[b]{2}{*}{$\begin{array}{c}\text { L.S.D. } \\
\text { (M) at } \\
0.05\end{array}$} & \multirow[b]{2}{*}{$\begin{array}{c}\text { L.S.D. } \\
\text { (HA) at } \\
0.05\end{array}$} & \multirow[b]{2}{*}{$\begin{array}{c}\text { L.S.D. } \\
\text { (M x HA) } \\
\text { at } 0.05\end{array}$} \\
\hline & & Ridges & Broadcasting & & & & & Ridges & Broadcasting & & & & \\
\hline \multirow{4}{*}{ Protein \% } & Untreated & 18.00 & 21.76 & 19.88 & & & & 19.80 & 25.7 & 22.75 & & & \\
\hline & 1200 & 20.18 & 21.58 & 20.88 & & & & 21.44 & 23.38 & 22.41 & & & \\
\hline & 2400 & 24.00 & 24.83 & 24.42 & 2.38 & 1.50 & 2.12 & 26.50 & 22.16 & 24.33 & N.S. & 1.63 & 2.33 \\
\hline & 3600 & 21.65 & 25.70 & 23.68 & & & & 26.30 & 26.63 & 26.47 & & & \\
\hline \multicolumn{2}{|c|}{ Average (M) } & 20.96 & 23.47 & & & & & 23.51 & 24.47 & & & & \\
\hline \multirow{4}{*}{$\mathbf{P} \%$} & Untreated & 0.38 & 0.46 & 0.42 & & & & 0.48 & 0.58 & 0.53 & & & \\
\hline & 1200 & 0.46 & 0.52 & 0.49 & & & & 0.52 & 0.57 & 0.55 & & & \\
\hline & 2400 & 0.52 & 0.56 & 0.54 & N.S. & 0.024 & 0.034 & 0.58 & 0.58 & 0.58 & 0.0223 & 0.0264 & 0.0373 \\
\hline & 3600 & 0.61 & 0.59 & 0.60 & & & & 0.59 & 0.63 & 0.61 & & & \\
\hline \multicolumn{2}{|c|}{ Average (M) } & 0.49 & 0.53 & & & & & 0.54 & 0.59 & & & & \\
\hline \multirow{4}{*}{$\mathbf{K} \%$} & Untreated & 0.72 & 1.00 & 0.86 & & & & 0.71 & 0.81 & 0.76 & & & \\
\hline & 1200 & 0.80 & 1.05 & 0.93 & & & & 0.88 & 0.99 & 0.94 & & & \\
\hline & 2400 & 0.85 & 1.07 & 0.96 & 0.066 & 0.041 & 0.058 & 0.96 & 1.05 & 1.01 & N.S. & 0.243 & 0.344 \\
\hline & 3600 & 0.98 & 1.09 & 1.04 & & & & 1.04 & 1.36 & 1.20 & & & \\
\hline \multicolumn{2}{|c|}{ Average (M) } & 0.84 & 1.05 & & & & & 0.90 & 1.05 & & & & \\
\hline \multirow{4}{*}{$\mathrm{Fe}\left(\mathrm{mg} \mathrm{kg}^{-1}\right)$} & Untreated & 64.53 & 83.67 & 74.10 & & & & 66.37 & 78.67 & 72.52 & & & \\
\hline & 1200 & 70.00 & 80.67 & 75.34 & & & & 76.00 & 82.10 & 79.05 & & & \\
\hline & 2400 & 79.33 & 85.17 & 82.25 & 4.77 & 5.28 & 7.46 & 84.17 & 86.80 & 85.49 & 4.17 & 2.00 & 2.84 \\
\hline & 3600 & 82.40 & 81.93 & 82.17 & & & & 88.00 & 86.80 & 87.40 & & & \\
\hline \multicolumn{2}{|c|}{ Average (M) } & 74.07 & 82.86 & & & & & 78.64 & 83.59 & & & & \\
\hline \multirow{4}{*}{$\operatorname{Mn}\left(\mathrm{mg} \mathrm{kg}^{-1}\right)$} & Untreated & 34.50 & 44.17 & 39.34 & & & & 36.40 & 44.77 & 40.59 & & & \\
\hline & 1200 & 38.80 & 50.67 & 44.74 & & & & 40.20 & 48.13 & 44.17 & & & \\
\hline & 2400 & 42.90 & 50.57 & 46.74 & 5.42 & 3.99 & 5.64 & 45.53 & 51.30 & 48.42 & 4.01 & 1.30 & 1.84 \\
\hline & 3600 & 40.10 & 54.70 & 47.40 & & & & 47.07 & 55.97 & 51.52 & & & \\
\hline \multicolumn{2}{|c|}{ Average (M) } & 39.08 & 50.03 & & & & & 42.30 & 50.04 & & & & \\
\hline & Untreated & 20.40 & 31.77 & 26.09 & & & & 23.73 & 30.43 & 27.08 & & & \\
\hline $7 \quad(-1)$ & 1200 & 28.00 & 32.70 & 30.35 & & & & 32.67 & 32.50 & 32.59 & & & \\
\hline Zn (mg kg $)$ & 2400 & 29.47 & 29.47 & 29.47 & N.S. & 2.88 & 4.07 & 36.00 & 35.47 & 35.74 & N.S. & 2.47 & 3.49 \\
\hline & 3600 & 29.93 & 29.97 & 29.95 & & & & 35.17 & 37.43 & 36.30 & & & \\
\hline Avera & (M) & 26.95 & 30.98 & & & & & 31.89 & 33.96 & & & & \\
\hline
\end{tabular}


REFERENCES

A.O.A.C. (1990). Official Methods of Analysis of Association of Official Analytical Chemists, 12th edition. Washington, D.C.

Agboola, S.A. (1979). An Agricultural Atlas of Nigeria. Oxford University Press, London, pp: 131-135.

Antoun, L.W., M.Z. Sahar and H.R. Hanaa (2010). Influence of compost, Nmineral and humic acid on yield and chemical composition of wheat plants. J. Soil Sci. and Agric. Engi. Mansoura Univ., 1(11): 1131-1143.

Benton, J., J. Benjamin, Jr. Wolf and A. H. Mills (1992). Macro-Micro Elements. Publishing Inc. Plant

Chapman, H.D. and R.T. Pratt (1978). Methods of Analysis for Soils, Plants and Water. Univ. California, Div.Agric Sci.169.

CoStat Ver. 6.311,(2005). Cohort software798 light house Ave. PMB320, Monterey, CA93940, and USA. email: info@cohort.com and Website: http://www.cohort.com/DownloadCoStatPart2.html

Dasharath, K., O. Sridevi and P.M. Salimath.(2007). In vitro multi application of sesame (Sesamum indicum L). Indian J. Crop Sci., 2(1): 121-126.

Eisa, S. A.l. (2011). Effect of amendments, humic and amino acids on increases soils fertility, yields and seeds quality of peanut and sesame on sandy soils. Res. J. Agric. \& Biol. Sci., 7(1): 115-125.

El-Bassiouny, H. S. M., B. A. Bakry, A. A. Attia and M. M. Abd Allah (2014). Physiological role of humic acid and nicotinamide on improving plant growth, yield, and mineral nutrient of wheat (Triticum durum) grown under newly reclaimed sandy soil. Agric. Sci.,5: 687-700.

Furat, S. and B. Uzun (2010). The use of agro-morphological characters for the assessment of genetic diversity in sesame (Sesamum indicum L). Plant Omics J., 3: 85-91.

Hermann, S., G. Joachim, S. Wilfried, W. Lutz and M. Wolfgang (2000). Effects of humus content, farmyard manuring and mineral $\mathrm{N}$ - fertilization on yield and soil properties in a long - term trial. J. PI. Nut. Soil Sci., 163: 657-662.

Hussein, K.H. and A.F. Hassan (2011). Effect of different levels of humic acids on the nutrient content, plant growth and soil properties under conditions of salinity. Soil and Water Res., 6(1):21-29.

Imoloame, E. O.(2004). Effects of seed rate and method of sowing on weed infestation, growth and yield of sesame (Sesamum indicum L.) in the sami arid zone of Nigeria. M.Sc. Dissertation. 37-50.

Imoloame, E. O., N. A. Gworgwor and S. D. Joshua (2007). Sesame (Sesamum indicum L.) weed infestation, yield and yield components as influenced by sowing method and seed rate in a Sudan Savanna agroecology of Nigeria. Afr. J. Agric. Res., 2 (10): 528-533.

Jackson, M.L.(1976). Soil Chemical Analysis. Constable and Co. L.T.P., London, England.

Khaled, A. S., M. G. Abd El-Kader and Z. M. Khalil (2012). Effect of soil amendments on soil fertility and sesame crop productivity under newly reclaimed soil conditions. J. Appl. Sci. Res., 8(3):1568-1575.

Klute, A. (1986). Methods of Soil Analysis. Part I, Soil Physical properties. ASA and SSSA, Madison, WI. 
Mackowiak, C.L., P.R. GrossI and B.G. Bugbee (2001). Beneficial effects of humic acid on micronutrient availability to wheat .Soil Sci.Soc.Am. J., 65:1744-1751.

Mkamilo, G. S. and D. Bedigian (2007). In PROTA (Plant Resources of Tropical Africa / Ressources végétales de l'Afrique tropicale), Wageningen, Netherlands. < http://database.prota.org/search.htm>. Accessed 30 November, 2008. (Van der Vossen, H. A. M. \& Mkamilo, G. S., eds.).

Moussa L., A., S. Fahmy and A. M. Shaltout (2006). Evaluation of some bacterial isolates and compost tea for bio- controlling Macrophomina phaseolina and Sclerotium rolfis infected sunflower.Egypt. J. Agric. Res., 48(5): 1331-1344.

Nasef, M.A., Kh. A. Shaban and A. F. Abd El-Hamide (2009). Effect of compost, compost tea and biofertilizer application on some chemical soil properties and rice productivity under saline soil condition. J. Agric. Mansoura Univ.34(4): 2609-2623.

Page, A.L., R.H. Miller and D.R. Keeney (1982). Methods of Chemical Analysis. Part 2: Chemical and Microbiological Properties (2nd Ed.). American Society of Agronomy, Inc. and Sci. Soc. of America, Inc. Publi., Madison, Wisconsin, U.S.A.

Porass, M.N., S. Gerges Jaklin, M. Sallam Amany and M.B. Adel (2010). Interactive effect of nitrogen fertilizer, bio-fertilizer and humic acid under saline conditions on yield, yield components and seed quality of sesame (Sesamum indicum L.). Egypt. J. Appl. Sci., 25(2B): 89-114.

Singaravel, K., T.N. Balasubramanian and R. Govindasamy (1993). Effect of humic acid on sesame growth and yield under two nitrogen levels. Indian J. Agron., 38(1): 147-149.

Singaravel, R. and R. Govindaswamy (1998). Effect of humic acid, nitrogen and biofertilizer on the growth and yield of sesame. J. Oil Seed Resh., 15(2): 366 ñ 67.

Snedecor, G.W. and W.G. Cochran (1990). Statistical Methods. 8th Ed. lowa State Univ., Press, Ames, lowa,USA. Analysis and Book.129-131.

Sommers, L.E. and D.W. Nelson (1972). Determination of total phophorus in soil. A rapid perchloric acid digestion procedure. Soil Sci. Soc. Amer. Proc., 36: 902-904.

Thanvanathan, K., M. Ganapathy, M. Parkash and V. Imayavaramban (2001). Nutrient uptake and quality characters of sesame (Sesamum indicum L) as influenced by micronutrient, Bio-fertilizer and phytohormanes. Sesame and Safflower Newslett., 16: 1013-1015.

Uzun, B. and M.I. Cağirgan (2009). Identifi cation of molecular markers linked to determinate growth habit in sesame. Euphytica., 166: 379-384.

Uzun, B., M.O. Ozbas, H.Canci and M.I. Cağirgan (2004). Heterosis for agronomic traits in sesame hybrids of cultivars $x$ closed capsule mutants. Acta. Agric. Sc. and Sect. B. Soil and Plant Sci., 54: 108- 112.

Wahdan, A. A. A., A. A. Awadalla and M. M. Mahmoud (2006). Response of some wheat-maize cropping sequence in a calcareous soil to some mineral or chelated micronutrient forms added to soil in combination with sulphur and organic manures. Fayoum J. Agric. Res. and Dev., 20(1): 25-39. 


\section{الملخص العربى \\ تأثير طريقة الزراعة وحامض الهيوميك على إنتاج السمسم \\ عصام إسماعيل إسماعيل قتديل \\ قسم الانتاج النباتى - كلية الزراعة سابا باشنا - جامعة الاسكندرية - مصر}

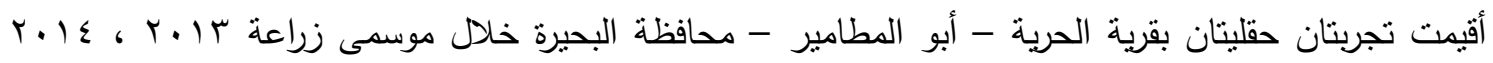

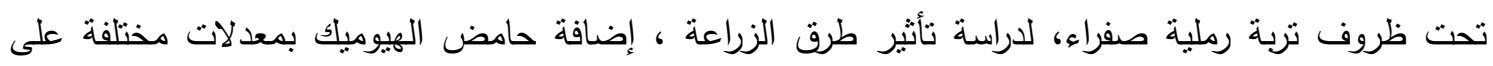

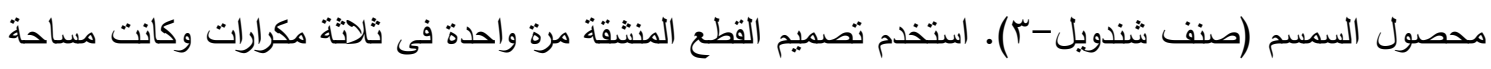

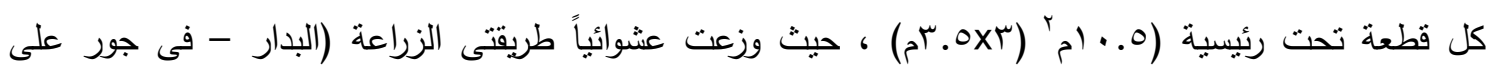

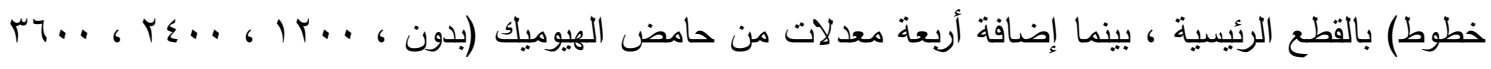

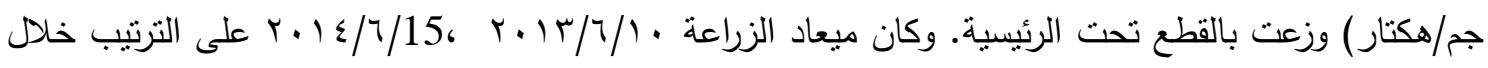
الموسمين

\section{وتتلخص أهم النتائج فيما يلى:}

- تفوقت طريقة الزراعة بدار فى أحواض حيث سجلت أعلى قيم لمعظم الصفات المدروسة مثل المحصول

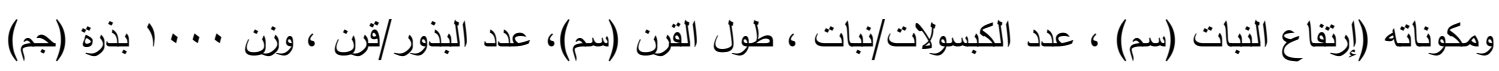

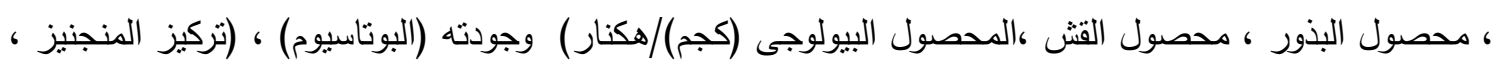

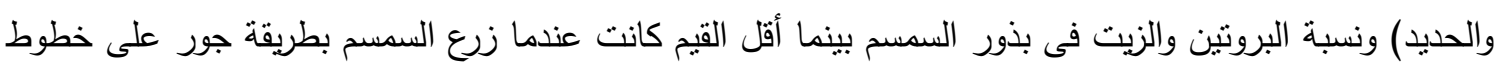

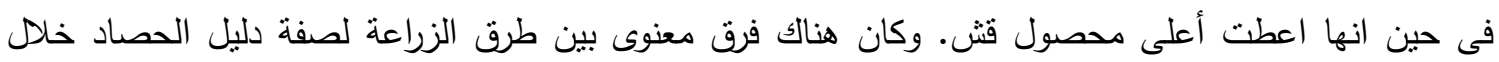
موسم الزراعة الأول فقط.

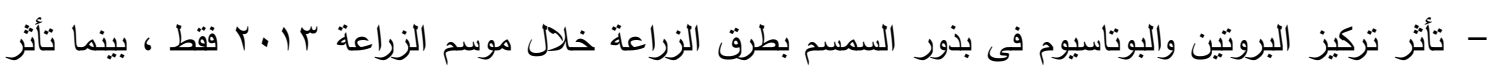

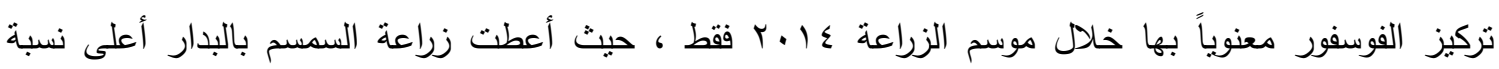

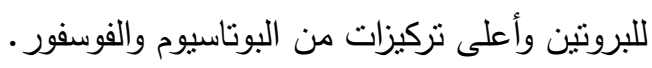

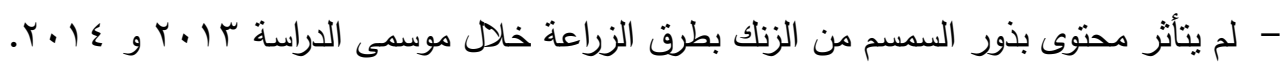

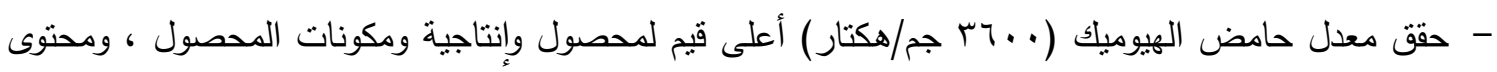
بذور السمسم من العناصر الصغرى والكبرى ، ونسبة الزيت ونسبة البروتين وايضاً تركيزات العناصر الكبرى

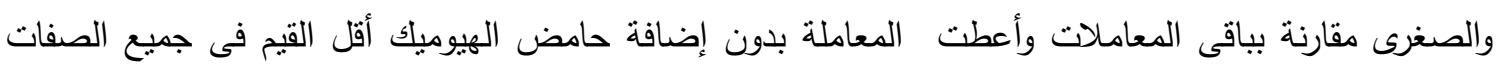
الدروسة تحت ظروف التجربة خلال الموسمين. - أعطى التذاخل بين زراعة السمسم بدار فى أحواض مع إضافة الهيوميك اسيد ( . . جس جم/هكتار) أعلى قيم

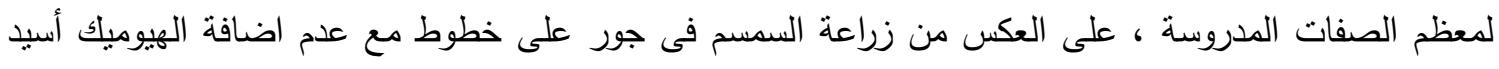
والتى أعطت أقل القيم. - توصى الدراسة بزراعة صنف السمس (شندويل r) بطريقة الزراعة بدار فى أحواض ، مع التسميد بحامض الهيوميك بمعدل ( . . بr جم/هكتار ) لزيادة انتاجيته ، وجودنه تحت ظروف منطقة الزراعة. 